УДК 811.161.2’373.611

Н. М. Малюга

\title{
ВИВЧЕННЯ СЛОВОТВОРЕННЯ В КОНТЕКСТІ ІСТОРИЧНОЇ СТИЛІСТИКИ
}

Малюга Н. М. Вивчення словотворення в контексті історичної стилістики.

У статті викладено історію становлення історичної стилістики, окреслено проблеми вивчення стилістичних можливостей словотворення, обгрунтовано потребу семантико-прагматичної диференціації словотворчих ресурсів української мови, умотивовано доцільність і перспективність дослідження стилістичного аспекту словотворення.

Ключові слова: дериваційна семантика, історична стилістика, словотворчі ресурси, стилістичний словотвір, стилістичні функції.

Малюга Н. Н. Изучение словообразования в контексте исторической стилистики.

В статье представлена история становления исторической стилистики, сформулированы проблемы изучения стилистических возможностей словообразования, обоснована потребность семантико-прагматической дифференциации словообразовательных ресурсов украинского языка, мотивирована целесообразность и перспективность изучения стилистического аспекта словообразования.

Ключевые слова: деривационная семантика, историческая стилистика, словообразовательные ресурсы, стилистическое словообразование, стилистические функции.

Malyuga N. M. Word formation study in the context of historic stylistics.

The article deals with the formation process of historic stylistics. The study problems of word formation stylistic potentials are formulated. The semantic and pragmatic necessity of differentiation Ukrainian word formation resources is substantiated. The reasonability and outlook of study stylistic aspect of word formation are motivated.

Key words: derivative semantics, historic stylistics, word formation potentials, stylistic word formation, stylistic functions.

Стилістична система національної мови, як найбільш залежна від позамовних факторів i динамічна, $\epsilon$ категорією історичною. Розвиненим i продуктивним у сучасній стилістиці $є$ синхронічний аспект дослідження стилістичної системи конкретної мови, який, крім теоретичного, має i прикладний характер, відповідає основному завданню сучасної лінгвістики - повному й усебічному вивченню мови 
як способу творення і вираження думки, як найважливішому засобу комунікаціі, способу пізнання світу, чиннику формування особистості.

Дослідженням стилістичної системи в діахронічному аспекті займається історична стилістика, коло джерел якої стояли В. Виноградов [2], Г. Винокур [3]. Історична стилістика вивчає формування i розвиток стилів упродовж усіх етапів розвитку національної мови, жанрово-мовленнєвих різновидів у зв'язку зі зміною їх екстралінгвістичних основ, динаміку розвитку виражальних одиниць, часову і якісну зміну конотації, становлення стилістичних ресурсів мови у процесі ऑï розвитку, хронологічно марковані стилістичні засоби. Термін «історична стилістика» i завдання ii дослідження представлені в роботі Г. Винокура «О задачах истории языка». Учений визначає підгрунтя функційного напрямку стилістики i пов’язує його з історією мови: «Перед нами нова проблема історії мови, без вивчення якої історія мови неповна. Вона становить зміст лінгвістичної дисципліни - стилістики, оскільки йдеться про історію мови - історичної стилістики» [3, с. 222].

М. Кожина обгрунтувала розвиток напрямку історичної (діахронічної) стилістики, дослідила проблеми взаємодії суміжних наукових дисциплін, застосувала комплексний міждисциплінарний підхід [5]. Стилістичний інтерес становить насамперед синхронічний словотвір, оскільки він відбиває співвіднесеність мотивованих i мотивуючих основ, а стилістична оцінка вимагає чіткого сприйняття словотвірної структури слова.

Стилістика, ураховуючи граматичні та лексичні значення засобів словотвору, головну увагу приділяє їх виражальній цінності, експресивній якості, можливостям їх підпорядкування певному змістові й меті висловлювання. Тільки наприкінці 50-х рр. ХХ ст. в українській лінгвістиці почалися спроби узагальнити розпорошені в різних граматичних i лексикологічних дослідженнях власне стилістичні спостереження. Так, наприклад, В. Ващенко у праці «Стилістичні явища в українській мові» [1], хоч і не подає загального огляду стилістичних властивостей засобів словотвору, але досить детально розглядає стилістичні функції суфіксації, префіксації та основоскладання. Спеціально досліджує стилістичні властивості засобів українського словотвору і словоскладання І. Чередниченко в «Нарисах 3 загальної стилістики сучасної української мови» [10]. Стилістичному використанню засобів словотвору приділяє увагу також А. Коваль у «Практичній стилістиці сучасної української мови». 
У працях С. Єрмоленко, Г. Їжакевич, Л. Мацько, О. Пономарева, В. Чабаненка, Т. Черторизької, у яких набула стрункості теорія стилістики, представлено характеристику стилістичних можливостей системних одиниць української мови, зокрема й дериватем.

Питанню про методи та методику стилістичних досліджень приділили увагу П. Дудик [4], В. Перебийніс [6], О Селіванова [7], Ю. Степанов [8; 9].

В. Костомаров запропонував нову концепцію стилістики, згідно 3 якою взаємодія i взаємопроникнення спричиняє зрушення співвідношення стилістики ресурсів мови і стилістики їх уживання (стилістики текстів).

Стилістичний аспект словотворення знайшов своє висвітлення у працях низки зарубіжних мовознавців, серед них Т. Анісімова, Л. Барлас, В. Бенке, В. Верещагіна, В. Виноградова, О. Гвоздєв, I. Голуб, М. Кожина, В. Лопатін, М. Максимов, І. Милославський, О. Пєшковський, I. Улуханов, М. Шанський; та українських учених: С. Бибик, В. Васильєвої, Т. Введенської, Г. Волкотруб, Л. Гумецької, Л. Дідківської, В. Русанівського А. Юханова та ін. Словотвірні ресурси, дериваційну структуру та процеси творення слів різних частин мови розглядали П. Білоусенко, Т. Возний, К. Городенська, Є. Карпіловська, Н. Клименко, І. Ковалик та ін.

Роботи названих учених здебільшого зорієнтовані на вивчення значень афіксів. Однак такий аспект аналізу залишає поза увагою реальну взаємодію одиниць словотвірної системи, зокрема, фактичні засади номінації, що грунтуються, поряд з іншими чинниками, і на категоріальній семантиці твірних основ відповідних лексикограматичних класів слів. Відповідно, такі дослідження не дають повного уявлення про словотвірну систему мови.

Назріла необхідність переходу від формантоцентричного до основоцентричного напрямку досліджень. В. Грещук уперше звернув увагу на необхідність зміщення в дослідженні словотвору акценту 3 дериваційних формантів на твірну базу, на потребу вивчення особливостей лексичної деривації 3 опертям на твірну основу як типологізувальний чинник у лінгвістиці й обгрунтував доцільність і актуальність основоцентричного підходу. Характерною особливістю сучасної дериватології $€$ зосередження уваги на вивченні системи дериватів, об'єднаних спільною твірною основою. Такий аспект вивчення словотвору передбачає встановлення адекватної йому одиниці класифікації й опису дериваційної системи. 
Основоцентричний підхід у вивченні словотвору переважає в дослідженнях Р. Бачкура, В. Горпинича, В. Грещука, I. Джочки, О. Земської, Л. Кислюк, В. Лопатіна, О. Микитин, І. Улуханова, О. Федотової та ін.

Стилістичне забарвлення мотивуючих основ та афіксів може бути неоднорідним, однак у цьому разі вплив на забарвлення утвореного слова в основному здійснює мотивуюча основа. У суфіксах розмовне забарвлення нерідко поєднується 3 емоційноекспресивним. Наприклад, розмовні слова із суфіксом -атин(а) характеризуються експресією несхвалення, негативною оцінкою (кислятина, поросятина, сірятина), відтінок несхвалення притаманний словам 3 розмовними суфіксами -ун (говорун), -уш(а) (дорогуша), -аст(ий) (горластий), -л(о) (громило). Ще більш знижене, просторічне забарвлення й експресію грубості, нехтування, приниження, несхвалення надають суфікси -лівк(а) (зрівнялівка),-н(я) (солдатня), -аш (торгаш).

Новий i перспективний напрямок словотвірних досліджень передбачає творчий аналіз семантичних функцій твірної основи. Здійснювана в рамках загального дослідження дериваційної семантики функційно-комунікативна інтерпретація семантичної сфери твірного слова надає останньому статусу особливої семантичної величини, якій властива функційна спрямованість, що визнається як його основна функційна ознака.

В. Лопатін та I. Улуханов чітко розмежовують значення морфеми і значення словотвірного типу, виробляють принципи опису словотвірної семантики, їхні праці засвідчують переміщення центру ономасіологічних досліджень із лексеми на дериватему; Х. Ядацька пропонує подивитися на нові слова крізь дериваційну систему мови (польської) як динамічне явище, у межах якого еволюціонували не лише окремі складники, а й словотвірні механізми загалом; мовознавець стоїть коло витоків створення засад синхронного за своїм підходом до аналізу та динамічного і діахронічного за інтерпретацією результатів аналізу соціолінгвістично зорієнтованого словотвору; О. Земська тлумачить словотвір як діяльність; О. Мартинцова активно вивчає словотвірну синонімію; Н. Лебедєва розглядає питання про розходження між потенціалом словотвірної системи i тим, як він реалізується в нормативному плані, пропонує спосіб експериментального дослідження слів різного ступеня узуальності / оказіональності; Г. Нещименко присвячує основні свої праці 
проблемам системного опису словотворення, співставному вивченню слов'янського словотворення, а також дериваційних процесів розмовної мови у світлі тенденцій мовної економії; О. Коряковцева аналізує словотвірні ресурси нових функційних стилів у співставному аспекті; I. Онхайзер аргументовано коментує стирання стилістичних меж у словотворенні і слововживанні; О. Лукашанець накреслює шляхи вирішення проблеми словотвірного розмежування стилів Інтернет-комунікації.

Широкий спектр теоретичних i практичних завдань дериватології привертає сьогодні пильну увагу славістів різних країн у зв'язку з відображенням у словотвірній номінації історії та культури народів як в історичній перспективі, так і в їх сучасному розвитку. У полі пильної уваги дериватологів перебувають закономірності та національна специфіка відображення суспільних змін у словотвірній номінації (М. Голев, Р. Драгічевич, О. Єрмакова, С. Карпіловська, Л. Кислюк, Н. Клименко, Г. Нещименко, О. Никитевич, В. Радева). У низці досліджень названих учених об'єктом спеціального розгляду постають окремі категорії та розряди дериватів, показові щодо відображення суспільно значущих явищ, а також перспективи вивчення словотворення за допомогою нових дослідницьких процедур, це допомагає представити загальнослов'янський контекст української деривації в усьому розмаїтті іiі виявів. Дослідники визначають співвідношення окремих способів і засобів номінації з окремими функційними стилями, систематизують співвідношення паралелізму, спеціалізації й інтеграції 3 погляду реалізації загальних принципів найменування в різних стилях (Н. Виноградова, І. Онхайзер).

Дослідження динаміки слов'янських мов на сучасному етапі репрезентують спільні та відмінні риси в способах і засобах номінації, передусім словотвірної як провідної в оновленні лексиконів. Теоретичні та практичні здобутки, важливі для аналізу тенденцій розвитку сучасної української мови, містять такі фундаментальні колективні монографії: «Українська мова» за редакцією С. Єрмоленко (Ополе, 1999), «Російська мова кінця ХХ століття (1985-1995)» за редакцією О. Земської (Москва, 2000, 2-е вид.) та «Словотворення / Номінація» за редакцією І. Онхайзер (Інсбрук / Ополє, 2003). Цінний досвід міжнародної співпраці в царині неології та неографії засвідчують доповіді учасників організованого вченими України тематичного блоку «Динаміка та стабільність лексичних i словотвірних систем слов'янських мов» на XIV Міжнародному з'ізді 
славістів (Охрид, 2008) та праці членів Комісії зі слов’янського словотворення при Міжнародному комітеті славістів - учасників секції «Нові явища в слов'янському словотворенні: система та функціонування» в межах програми Міжнародного наукового симпозіуму «Слов'янські мови та культури в сучасному світі» (Москва, 2009): К. Вашакової, О. Срмакової, .Карпіловської, К. Клещової, Н. Клименко, М. Кронгауза, І. Онхайзер, О. Петрухіної, В. Радевої, І. Улуханова та ін.

Проблеми аналізу форми, семантики та особливості функціонування нової лексики в різних слов'янських мовах досліджують російські, польські, білоруські, болгарські, чеські лінгвісти: Ц. Аврамова, Ю. Балтова, І. Боздехова, Н. Валгіна, О. Земська, О. Коряковцева, В. Костомаров, Л. Крисін,О. Лукашанець, О. Маринова, Г. Нещименко, Г. Ніколаєв, О. Остапчук та ін. Під час вивчення інноваційних процесів посилився інтерес до розгляду конкурентних словотворчих формантів. Цінними для осмислення можливостей та функцій конкурентних способів i засобів словотворення в різних слов'янських мовах є публікації О. Земської, Є. Карпіловської, Н. Клименко, О. Коряковцевої, О. Лукашанця, Г. Нещименко, І. Онхайзер, О. Петрова, О. Петрухіної, Т. Попової, Л. Рацибурської, І. Улуханова, 3. Харитончик та ін.

Проте в українському мовознавстві, як i в зарубіжній лінгвістиці, на сьогодні ще відсутні праці, автори яких обирали б конкурентні номінації об'єктом спеціального дослідження і ставили б завдання з'ясувати причини та джерела їхньої появи, формальносемантичну будову, функціональні властивості, а отже, чинники, що сприяють стійкості таких груп, можливості їх закріплення в системі мови і в мовній практиці або усталенню як нормативного лише одного 3 наявних конкурентів. Водночас україністи в різний час уже звертали увагу на сукупності номінацій одного об'єкта чи поняття, які здатні взаємозамінюватися в мовленні та співіснувати в системі мови. Серед праць, у яких засвідчено і в різних аспектах проаналізовано групи конкурентних одиниць українського лексикону ХІХ-XX ст., слід назвати передусім дослідження А. Грищенка, М. Жовтобрюха, I. Ковалика, Л. Колібаби, В. Коломієць, К. Ленець, А. Лучик, О. Муромцевої, Ф. Нікітіної, М. Пилинського, Л. Родніної, Н. Сологуб, Г. Щербатюк. Особливостям оновлення словникового складу української мови в нових умовах іï функціонування в незалежній Україні присвячено праці Б. Ажнюка, Ф. Бацевича, 
С. Бибик, Я. Битківської, І. Браги, К. Брітікової, Г. Віняр, Г. Вокальчук, К. Городенської, С. Срмоленко, А. Загнітка, О. Зарецького, Є. Карпіловської, Л. Кислюк, Н. Клименко, Ж. Колоїз, Т. Коць, Д. Мазурик, Г. Мінчак, А. Нелюби, О. Пономарева, Ю. Романюк, О. Рудь, І. Самойлової, С. Соколової, Л. Ставицької, О. Стишова, Л. Струганець, Г. Сюти, О. Тараненка, С. Чемеркіна, Г. Яворської та інших учених.

Словотвір стає об'єктом зацікавлення стилістів у таких випадках: 1) якщо мотивоване слово набуває стилістичного забарвлення, не властивого мотивуючому; 2) якщо афіксація сприяє функційно-стильовому закріпленню слова; 3) якщо особливості словотворення обмежують сферу використання слів, які функціонують тільки в діалектах або отримують професійний чи жаргонний відтінок; 4) якщо особливості словотворення стають причиною архаїзації слова, що поступається своїм місцем в активному словнику синоніму 3 іншими афіксами; 5) якщо словотворення використовується як джерело мовленнєвої експресії при створенні оказіоналізмів.

Виокремлення словотвірної стилістики сприяє не тільки повнішому охопленню питань стилістичного словотвору, загальному їх осмисленню, чіткішому виявленню стилістичної ролі окремих способів і засобів словотворення, зокрема в їх взаємодії, але й виробленню найдоцільніших принципів опису i дослідження зібраного матеріалу, уніфікації методів його вивчення.

У мовознавчій літературі існує кілька принципів аналізу стилістичних функцій засобів словотвору. Серед них цілком логічним видається суто «стилістичний» підхід, який забезпечує аналіз окремих засобів і способів словотвору за їх належністю до таких важливих стилістичних категорій, як функціональні мовні стилі, 3 подальшим виявленням їх експресивних властивостей. Цей шлях $\epsilon$ складним через недостатню розробленість самого поняття функційних стилів мови, через суперечливість поглядів на їх кількість, розмежування, що пояснюється об’єктивною складністю, широтою і суперечливістю цього питання. За такого підходу неминучі повторення, оскільки в різних функційних стилях одні й ті самі словотворчі засоби відіграють подібну роль. Інший принцип полягає в дослідженні стилістичних функцій окремих словотворчих засобів, наприклад, суфіксації, префіксації. Але й цей принцип, у свою чергу, має певні недоліки, оскільки стилістичні функції різних засобів 
словотвору часто є близькими або доповнюють одна одну, а при такому дослідженні вони розглядаються у відриві; негативно впливають на компактність і стрункість викладу повторення, які при цьому неминуче виникають. Не завжди вдається розмежувати стилістичні властивості певного словотворчого засобу і стилістичні властивості слова, яких воно набуває в мовленні залежно від певного контексту, завдяки іншим стилістичним засобам. У такому разі словотворчий засіб відіграє тільки допоміжну роль для вираження строкатої і суперечливої гами емоцій і оцінок, що важко піддається систематизації і врахуванню.

Виявленню стилістичної ролі окремих способів i засобів словотворення присвячено дисертації Т. Вільчинської «Семантикословотвірна характеристика оцінних назв осіб в українській мові», I. Демешко «Валентність суфіксів -ець, -ок в українській мові», I. Думчака «Універбація в українській мові», Т. Івасишиної «Синонімія словотворчих афіксів», В. Іващенко «Конотативно-оцінний аспект семантики назв осіб за родом діяльності, місцем проживання та національною належністю», Н. Кислициної «Прикметники зі значенням позитивної оцінки як фрагмент мовної картини світу (на матеріалі російської, української та англійської мов)», Ж. Колоїз «Українська оказіональна деривація», А. Маймакової «Словотворча семантика суфіксів відносних прикметників та ії інтерпретація носіями мови», С. Семенюк «Формування словотвірної системи іменників 3 модифікаційним значенням жіночої статі в новій українській мові» та ін.

У лінгвоукраїністиці набула розвитку стилістика мовних засобів (мовних ресурсів), яка, оперуючи одиницями конкретних мовних рівнів (лексичного, граматичного, словотвірного) i застосовуючи власне словотвірні методи студіювання, репрезентує опис стилістичної системи української мови. Здійснено дослідження стилістики індивідуального мовлення, зорієнтовані на вивчення своєрідності мови окремого індивіда, їі особливих реалізацій у різних функційних стилях: К. Баценко (здрібнілі i згрубілі суфікси іменників), К. Борщ (суб'єктивно-модальний потенціал префіксальних дериватів у поезії В. Стуса), Н. Босаківська (особливості словотвору усного мовлення), І. Браїлко (дериваційний потенціал дієслова в українській поезії 20-30 pp. XX ст.), Г. Горюк (демінутиви в мовленні М. Коцюбинського та О. Кобилянської), І. Губаржевський (демінутиви у творах Т. Шевченка), Т. Коць (складні назви предметних реалій і абстрактних понять у мові сучасних 3MI), Т. Кузнєцова (механізми 
утворення «сімейних» слів у розмовно-побутовому варіанті мови), К. Ленець (суфікси іменників - назв осіб жіночого та середнього роду), О. Муромцева (дієслівні складення в мові Панаса Мирного), Л. Мялковська (абстрактні іменники як компонент ідіостилю Валер'яна Підмогильного), М. Плющ (суфіксація як засіб гумору та іронії в «Енеїді» І. Котляревського та засіб інтимізації в «Кобзарі» Т. Шевченка), Л. Пустовіт, Г. Сюта (мова поезії 50-80 рр. ХХ ст.), Б. Рубчак (демінутиви в народній поезіï), О. Рудь (стилістичний словотвір складних прикметників у поетичній мові), Г. Сагач (експресивний словотвір у фольклорі), О. Синявський (демінутиви у Шевченковій мові), О. Стишов (динамічні процеси в лексиці української мови 80-90 pp. XX ст., тенденції українського словотворення), I. Фекета (жіночі особові назви в українському літературному мовленні), В. Чабаненко (пестливо-зменшувальні форми в мові Марка Вовчка), Л. Шулінова (стилістичні засоби словотвору в художньому мовленні Лесі Українки), Т. Юрченко (експресивність словотвірних оказіоналізмів у прозі П. Загребельного) та ін.

У межах кожної окремої частини мови виділяють певні типи основ (основоцентричний підхід), від яких значною мірою залежить уживання тих чи тих словотворчих засобів й експресивне забарвлення слова. За такого підходу чітко розмежовуються групи словотворчих засобів з урахуванням їх найзагальніших стилістичних властивостей. Досліджуючи специфіку похідної одиниці, не можна нехтувати аналізом ролі базової частини, оскільки врахування категорійної семантики твірних основ відповідних лексико-семантичних класів, на яких грунтуються фактичні засади номінації, допомагає з'ясувати реальну взаємодію одиниць словотвірної системи.

Наголошуємо на взаємодоповнюваності формантоцентричного й основоцентричного вивчення деривації. Розгляд функційного навантаження твірної основи в дериваційних актах дозволить вирішити низку проблем, що залишилися поза увагою в інших розвідках, зокрема питання про конототивні інгредієнти твірного слова, про екстралінгвістичні чинники, що впливають на використання різних класів твірних основ, про інвентар словотвірних формантів для різних класів твірних основ тощо.

Спосіб стилістичної характеристики синонімічних словотвірних типів не дає змоги, однак, розглянути зі стилістичної позиції всі словотвірні типи, адже далеко не завжди вони утворюють групи, що характеризуються спільним значенням. Завдання функційно- 
стилістичної характеристики словотвірних типів досить складне, оскільки є чимало 3 них, що виявляють продуктивність одночасно в різних сферах використання. Для функційно-стилістичної характеристики словотвірних засобів становить інтерес питання про те, які способи словотворення активізуються в книжних і розмовних стилях. Несамостійність словотвірних афіксів, існування лише в складі слова ставить їхнє стилістичне забарвлення залежно від лексико-стилістичної парадигми.

Отже, як свідчить огляд спеціальної літератури, в україністиці назріла потреба дослідження механізму створення оцінних значень засобами словотворення; співвідношення окремих засобів номінації 3 окремими функційними стилями; паралелізму і спеціалізації з погляду реалізації загальних принципів найменування в різних стилях. На часі увага мовознавців до прагматики твірного слова; до стилістичних парадигм, що засновуються на тотожності (чи близькості) основного значення одиниць, які до неї входять. У перспективі - вивчення тенденції до стилістичної однорідності поєднуваних морфем.

\section{Література}

1. Ващенко В. С. Стилістичні явища в українській мові. Ч. 1 / Василь Семенович Ващенко. - Харків : Вид-во ХДУ, 1958. - 228 с.

2. Виноградов В. В. Проблемы русской стилистики / Виктор Владимирович Виноградов. - М. : Высшая школа, 1961. - 320 с.

3. Винокур Г. О. О задачах истории языка / Г. О. Винокур // Избранные работы по русскому языку. - М. : Учпедгиз, 1959. - С. 207-226.

4. Дудик П. С. Методологія, методи й методика стилістики / П. С. Дудик // Стилістика української мови : [навчальний посібник]. - К. : ВЦ «Академія», 2005. C. 43-46.

5. Кожина М. Н. Стилистика русского языка : [учеб. пособие для студентов фак. рус. яз. и литературы пед. ин-тов] / Маргарита Николаевна Кожина. - М. : Просвещение, 1983. - 223 с.

6. Перебийніс В. С. Методи дослідження стилістики мови і стилістики мовлення / В. С. Перебийніс // Теоретичні проблеми лінгвістичної стилістики. - К. : Наукова думка, 1972. - С. 47-70.

7. Селіванова О. Лінгвометодологія - наукова парадигма - епістема / Олена Селіванова // Науковий вісник Чернівецького національного університету : зб. наук. праць / наук. ред. Б. І. Бунчук. - Чернівці : ЧНУ, 2009. - Вип. 475-477 : Слов'янська філологія. - С. 200-206.

8. Степанов Ю. С. Методы и принципы современной лингвистики / Ю. С. Степанов. - М. : Наука, 1975. - 308 с.

9. Степанов Ю. С. Язык и метод: к современной философии языка / Юрий Сергеевич Степанов. - М. : Школа «Языки русской культуры», 1998. - 397 с.

10. Чередниченко I. Г. Нариси з загальної стилістики сучасної української мови / Іван Григорович Чередниченко. - К. : Рад. школа, 1962. - 495 с. 